\title{
Spatial variability of glacial changes and their effects on water resources in the Chinese Tianshan Mountains during the last five decades
}

\author{
WANG Puyu ${ }^{1 *}$, LI Zhongqin ${ }^{1,2}$, HUAI Baojuan ${ }^{1}$, WANG Wenbin ${ }^{1}$, LI Huilin ${ }^{1}$, WANG Lin $^{1}$ \\ ${ }^{1}$ State Key Laboratory of Cryospheric Sciences/Tianshan Glaciological Station, Cold and Arid Regions Environmental and \\ Engineering Research Institute, Chinese Academy of Sciences, Lanzhou 730000, China; \\ ${ }^{2}$ College of Geography and Environmental Science, Northwest Normal University, Lanzhou 730070, China
}

\begin{abstract}
Changes in glaciers in the Chinese Tianshan Mountains have been analyzed previously. However, most previous studies focused on individual glaciers and/or decentralized glacial basins. Moreover, a majority of these studies were published only in Chinese, which limited their usefulness at the international level. With this in mind, the authors reviewed the previous studies to create an overview of glacial changes in the Chinese Tianshan Mountains over the last five decades and discussed the effects of glacial changes on water resources. In response to climate change, glaciers in the Tianshan Mountains are shrinking rapidly and are ca. $20 \%$ smaller on average in the past five decades. Overall, the area reduction of glacial basins in the central part of the Chinese Tianshan Mountains is larger than that in the eastern and western parts. The spatial differentiation in glacial changes are caused by both differences in regional climate and in glacial factors. The effects of glacial changes on water resources vary in different river basins due to the differences in glacier distribution, characteristics of glacial change and proportion of the glacier meltwater in river runoff.
\end{abstract}

Keywords: Chinese Tianshan Mountains; climate change; glacial change; regional differences; water resources

Citation: WANG Puyu, LI Zhongqin, HUAI Baojuan, WANG Wenbin, LI Huilin, WANG Lin. 2015. Spatial variability of glacial changes and their effects on water resources in the Chinese Tianshan Mountains during the last five decades. Journal of Arid Land, 7(6): 717-727. doi: $10.1007 / \mathrm{s} 40333-015-0086-0$

Mountain glaciers serve as indicators of climate change, which are important for maintaining ecological health and the sustainable development of industry and agriculture. Glaciers in the Tianshan Mountains have tended to retreat rapidly since the end of the Little Ice Age (LIA) as the results of increase in air temperature and changes in precipitation forms with more liquid than solid at high elevations. Changes in the hydrologic cycle and the spatial-temporal distribution of glacial meltwater caused by changes in glaciers will have a significant influence on production and people's livelihood. Recently the phenomenon has aroused wide concern. Aizen et al. (2007) reported that during 1943 to 2003 the glacier areas decreased by $12.8 \%$ and $15.8 \%$ in the Akshiirak glacierized massif in the central Tianshan Mountains and in the Ala Archa glacier basin in northern Tianshan Mountains, respectively. Bolch (2007) found that glacial area decreased more than $32 \%$ from 1955 to 1999 in the valleys of Zailiyskiy and Kungey Alatau in northern Tianshan Mountains, which was because of the increase in summer temperatures. The surface areas of 335 investigated glaciers in eastern Terskey-Alatoo Range of the Tianshan Mountains decreased by $76 \mathrm{~km}^{2}$ (19\%) as compared to that in the LIA (Kutuzov and Shahgedanova, 2009). This was the observed changes due to climatic warming and precipitation anomalies. Narama et al. (2010) reported that glacier areas

"Corresponding author: WANG Puyu (E-mail: wangpuyu@lzb.ac.cn) 
decreased by $19 \%, 12 \%, 12 \%$ and $9 \%$ in the Pakem region, Ili-Kungőy region, 718 At-Bashy region and SE-Fergana region, respectively, over the period from 1970 to 2000. Regional differences in glacier area changes were related to local climatic conditions, the altitudinal distribution of the glaciers and the relative proportion of glaciers in different size classes. Li et al. (2006) estimated that the total glacier areas in the middle Chinese Tianshan Mountains decreased by $13 \%$ in 1963 to 2000 and the rate of glacial recession increased after 1986. Differences of glacial changes were observed between the East and the West Tianshan Mountains. The representative glaciers of the East and the West Tianshan Mountains were Urumqi Glacier No. 1 (UG1) and Tuyuksu Glacier with glacier net mass balances of -235 and $-409 \mathrm{~mm}$ water equivalent and the mean annual glacier area reduction rates of $0.29 \%$ and $0.46 \%$, respectively, during the past ca. 40 years (Wang et al., 2008).

The number of glaciers in Chinese portion of the Tianshan Mountains accounts for $57 \%$ the total glaciers in TianShan Mountains and the glaciers are important water resources for regional economic development (Shi et al., 2005). Most previous studies focused on individual glaciers and glacial basins within the Chinese Tianshan Mountains (Liu et al., 2006; Li et al., 2010; Wang et al., 2009, 2011, 2012). A majority of these were only published in Chinese and thus remain unknown to the international scientific communities. Therefore, it is important to comprehensively analyze and quantify recent glacial changes in the Chinese Tianshan Mountains and their effects on water resources.

This study selected 12 monitored glaciers and 9 glacial basins in the Chinese Tianshan Mountains, which should be sufficient to represent the overall glacial changes across the Chinese Tianshan Mountains (Fig. 1). We use topographic maps, satellite images, digital elevation models, meteorological data and previous studies of individual glaciers and small regional glaciers to analyze and discuss the regional differences in glacial changes, their driving factors, and their effects on water resources.

\section{Study area and data}

\subsection{Study area}

Tianshan Mountains $\left(39^{\circ}-46^{\circ} \mathrm{N}, 69^{\circ}-95^{\circ} \mathrm{E}\right)$ is one of the largest mountain ranges in Central Asia and transverse part of China, Kazakhstan, Kyrgyzstan and Uzbekistan. Approximately $2 / 3$ of the Tianshan Mountains lies within China (ca. 1,700 km) and spans Xinjiang Uygur autonomous region. The average elevation of the mountain peaks is $4,000 \mathrm{~m}$ asl and the highest point is Tomur Peak at 7,435 $\mathrm{m}$ asl in Wensu county (Shi et al., 2005). The 7,934 glaciers in

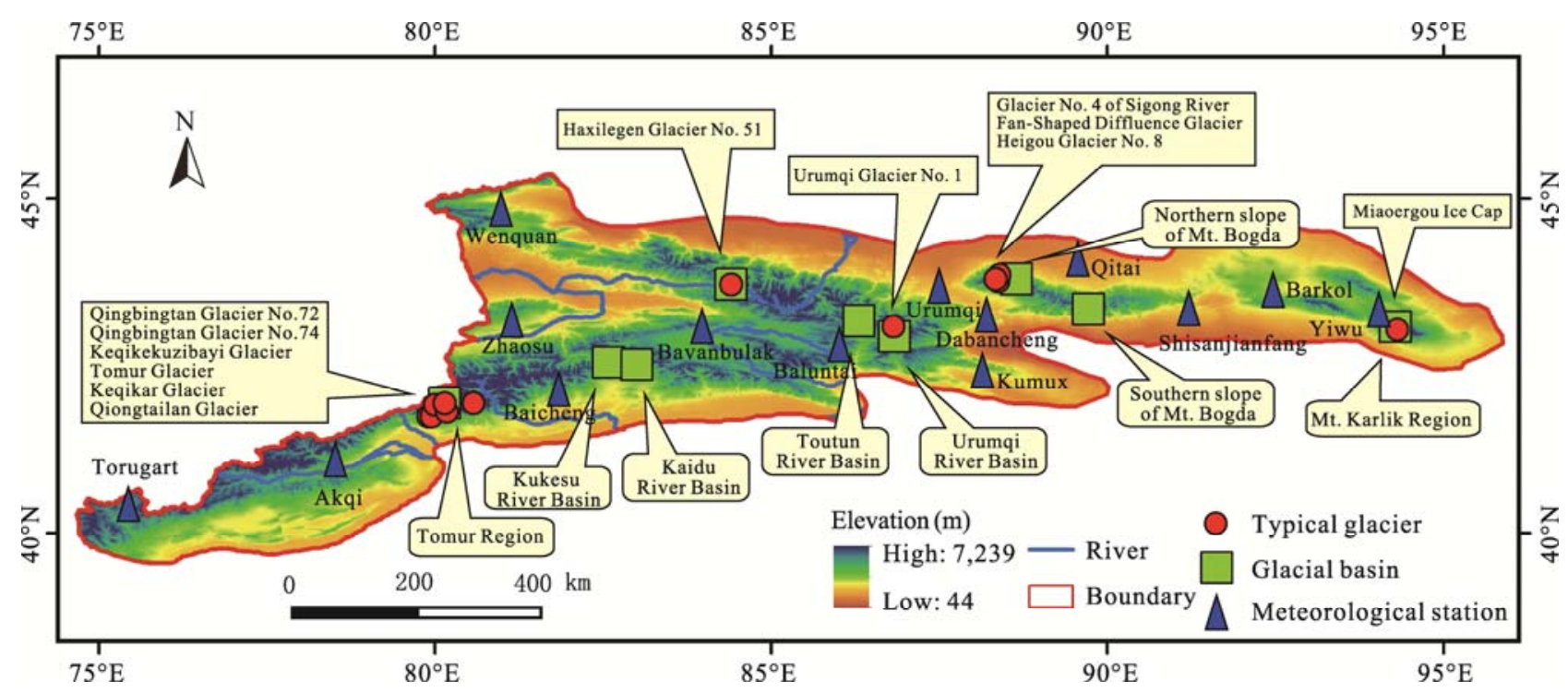

Fig. 1 Locations of 12 monitored glaciers, 9 glacial basins and 14 meteorological stations in the Chinese Tianshan Mountains 
the Chinese Tianshan Mountains cover a total area of $7,179.77 \mathrm{~km}^{2}$ and contain an ice volume of $707.95 \pm 45.05 \mathrm{~km}^{3}$, accounted for $16.33 \%$, $13.87 \%$, and $15.75 \%$ of the total number, area and volume of glaciers in China (Liu et al., 2015). Available information of the selected 12 monitored glaciers and 9 glacial basins were presented in Table 1.

\subsection{Data and sources}

Glaciers of the Chinese Tianshan Mountains have been studied since 1959 (Wang et al., 1983; Mountaineering and Expedition Term of Chinese Academy of Sciences, 1985; Cao, 1993; Su, 1998). Twelve monitored glaciers and nine glacial basins were selected to determine glacial changes including glacier area, length, thickness, and volume (Fig. 1; Tables 1 and 2). However, the long-term and continuous observations of glaciers are lacking except for UG1, which is the only glacier in China being included in the World Glacier Monitoring Service with more than 50 years monitoring history in China. The ground observation can provide a reliable basis for the study of glacial changes ( $\mathrm{Li}$ et al., 2010). Using common methods, we used topographic maps, various satellite images, and digital elevation models to compare and investigate the changes of the studied glacial basins. In addition, references such as the "Glacier Inventory III of China" (Lanzhou Institute of Glaciology and Geocryology and Chinese Academy of Sciences, 1986a, b, c, d), "Concise Chinese Glacier Inventory" (Shi, 2005) and "Glacier Water Resources in China" (Yang, 1991) were used to gather basic information of the glaciers and related dynamic water resources background in Xinjiang. Meteorological data from 14 meteorological stations (Fig. 1; Table 3) were obtained from the China Meteorological Data Sharing Service System (http://cdc.cma.gov.cn). All these collected data were between 1960 and 2009. Following the methods of $\mathrm{Li}$ et al. (2010) and Wang et al. (2011), single-element regression was adopted to analyze the linear trends of temperature and precipitation.

Table 1 Characteristics and available information of 12 monitored glaciers in the Chinese Tianshan Mountains

\begin{tabular}{|c|c|c|c|c|c|c|c|}
\hline Glacier (region) & Location & $\begin{array}{l}\text { Area } \\
\left(\mathrm{km}^{2}\right)\end{array}$ & $\begin{array}{l}\text { Length } \\
(\mathrm{km})\end{array}$ & $\begin{array}{l}\text { Elevation } \\
\text { range }(\mathrm{m})\end{array}$ & Aspect & Data available (year) & Source \\
\hline $\begin{array}{l}\text { Qingbingtan Glacier No. } 72 \\
\text { (Tomur Region) }\end{array}$ & $\begin{array}{l}41^{\circ} 45^{\prime} \mathrm{N} \\
79^{\circ} 54^{\prime} \mathrm{E}\end{array}$ & 7.27 & 7.4 & $3,560-5,986$ & South & $\begin{array}{l}1964,2003,2008 \\
2009\end{array}$ & $\begin{array}{l}\text { Wang et al. (2011, 2013); Luo } \\
\text { et al. (2012) }\end{array}$ \\
\hline $\begin{array}{l}\text { Qingbingtan Glacier No. } 74 \\
\text { (Tomur Region) }\end{array}$ & $\begin{array}{l}41^{\circ} 45^{\prime} \mathrm{N} \\
79^{\circ} 57^{\prime} \mathrm{E}\end{array}$ & 9.55 & 7.5 & $3,680-5,600$ & South & $1964,2003,2009$ & Wang et al. (2013) \\
\hline $\begin{array}{l}\text { Keqikekuzibayi Glacier } \\
\text { (Tomur Region) }\end{array}$ & $\begin{array}{l}41^{\circ} 57^{\prime} \mathrm{N} \\
80^{\circ} 34^{\prime} \mathrm{E}\end{array}$ & 25.77 & 10.2 & $3,320-4,600$ & Southeast & $1964,2003,2007$ & Wang et al. (2013) \\
\hline $\begin{array}{l}\text { Tomur Glacier } \\
\text { (Tomur Region) }\end{array}$ & $\begin{array}{l}41^{\circ} 55^{\prime} \mathrm{N} \\
80^{\circ} 00^{\prime} \mathrm{E}\end{array}$ & 310.14 & 41.5 & $2,780-7,434$ & Southwest & $1964,2003,2009$ & Wang et al. ( 2013) \\
\hline $\begin{array}{l}\text { Keqikar Glacier } \\
\text { (Tomur Region) }\end{array}$ & $\begin{array}{l}41^{\circ} 49^{\prime} \mathrm{N} \\
80^{\circ} 10^{\prime} \mathrm{E}\end{array}$ & 83.56 & 25 & $3,020-, 6,342$ & South & $\begin{array}{l}1942,1976,1981 \\
1985,1989,1999 \\
2002,2003,2005\end{array}$ & $\begin{array}{l}\text { Xie et al. ( 2006); Zhang et al. } \\
(2006)\end{array}$ \\
\hline $\begin{array}{l}\text { Qiongtailan Glacier } \\
\text { (Tomur Region) }\end{array}$ & $\begin{array}{l}41^{\circ} 57^{\prime} \mathrm{N} \\
80^{\circ} 08^{\prime} \mathrm{E}\end{array}$ & 165.38 & 23.8 & $3,080-7,434$ & Southeast & $\begin{array}{l}1942,1964,1976 \\
2003\end{array}$ & $\begin{array}{l}\text { Su et al. (1985); Wang et al. } \\
(2013)\end{array}$ \\
\hline $\begin{array}{l}\text { Haxilegen Glacier No. } 51 \\
\text { (Kuitun River Basin) }\end{array}$ & $\begin{array}{l}43^{\circ} 43^{\prime} \mathrm{N} \\
84^{\circ} 24^{\prime} \mathrm{E}\end{array}$ & 1.48 & 1.7 & $3,400-4,000$ & Northeast & $\begin{array}{l}1964,1999,2004, \\
2006\end{array}$ & $\begin{array}{l}\text { Jing et al. (2002); Jiao et al. } \\
\text { (2009); Li et al. (2010); Wang } \\
\text { et al. (2014) }\end{array}$ \\
\hline $\begin{array}{l}\text { Urumqi Glacier No. } 1 \\
\text { (Urumqi River Basin) }\end{array}$ & $\begin{array}{l}43^{\circ} 06^{\prime} \mathrm{N} \\
86^{\circ} 49^{\prime} \mathrm{E}\end{array}$ & 1.94 & 2.2 & $3,730-4,486$ & Northeast & $\begin{array}{l}1962,1973,1981 \\
1986,1994,2001 \\
2006,2009\end{array}$ & $\begin{array}{l}\text { Li et al. (2010); Sun et al. } \\
\text { (2013); Wang et al. (2014); } \\
\text { Zhang et al. (2014) }\end{array}$ \\
\hline $\begin{array}{l}\text { Glacier No. } 4 \text { of Sigong River } \\
\text { (Northern slope of Mt. Bogda) }\end{array}$ & $\begin{array}{l}43^{\circ} 49^{\prime} \mathrm{N} \\
88^{\circ} 21^{\prime} \mathrm{E}\end{array}$ & 3.33 & 3.2 & $3,600-4,350$ & West & $\begin{array}{l}1962,1981,2006 \\
2009\end{array}$ & $\begin{array}{l}\text { Wu et al. (1983); Wang et al. } \\
\text { (2012); Wu et al. (2011) }\end{array}$ \\
\hline $\begin{array}{l}\text { Fan-Shaped Diffluence Glacier } \\
\text { (Northern slope of Mt. Bogda) }\end{array}$ & $\begin{array}{l}43^{\circ} 48^{\prime} \mathrm{N} \\
88^{\circ} 20^{\prime} \mathrm{E}\end{array}$ & 3.47 & 4.3 & $3,620-5,445$ & Northwest & $1962,2006,2009$ & $\begin{array}{l}\text { Wu et al. (1983); Li et al. } \\
\text { (2010) }\end{array}$ \\
\hline $\begin{array}{l}\text { Heigou Glacier No. } 8 \\
\text { (Southern slope of Mt. Bogda) }\end{array}$ & $\begin{array}{l}43^{\circ} 46^{\prime} \mathrm{N} \\
88^{\circ} 23^{\prime} \mathrm{E}\end{array}$ & 5.71 & 7.1 & $3,380-5,445$ & South & 1962, 1986, 2009 & Wang (1991); Li et al. (2010) \\
\hline $\begin{array}{l}\text { Miaoergou Ice Cap } \\
\text { (Mt. Karlik Region) }\end{array}$ & $\begin{array}{l}43^{\circ} 02^{\prime} \mathrm{N} \\
94^{\circ} 20^{\prime} \mathrm{E}\end{array}$ & 3.45 & 2.4 & $3,840-4,500$ & Southwest & $\begin{array}{l}1972,1981,2005 \\
2007\end{array}$ & $\begin{array}{l}\text { Li et al. (2007); Li et al. } \\
(2010)\end{array}$ \\
\hline
\end{tabular}


Table 2 Statistics of area and terminus changes for 9 glacial basins throughout the Chinese Tianshan Mountains during the last five decades

\begin{tabular}{|c|c|c|c|c|c|c|}
\hline Region & $\begin{array}{c}\text { Number of } \\
\text { glaciers studied }\end{array}$ & Period & $\begin{array}{c}\text { Number } \\
\text { disappeared }\end{array}$ & $\begin{array}{c}\text { Area shrinkage } \\
(\%)\end{array}$ & $\begin{array}{l}\text { Terminus retreat } \\
(\mathrm{m} / \mathrm{a})\end{array}$ & Source \\
\hline Tomur Region & 483 & $1964-2003$ & - & 8.8 & 6.2 & Li et al. (2010) \\
\hline Kukesu River Basin & 293 & 1963-2004 & 11 & 18.9 & 7.0 & Gao et al. (2011) \\
\hline Kaidu River Basin & 70 & $1963-2000$ & - & 13.0 & $\begin{array}{c}4-7(1963-1986) \\
5-12(1986-2000)\end{array}$ & Li et al. (2006) \\
\hline Kuitun River Basin & 167 & 1964-2004 & 11 & 15.4 & 3.5 & Li et al. (2010) \\
\hline \multirow{2}{*}{ Toutun River Basin } & 80 & $1959-1993$ & 3 & 14.9 & & Kang (1996) \\
\hline & 172 & 1964-2005 & 5 & 31.5 & 4.8 & Li et al. (2010) \\
\hline \multirow{2}{*}{ Urumqi River Basin } & 150 & 1964-1992 & \multirow{2}{*}{11} & 13.8 & \multirow{2}{*}{5.0} & Chen et al. (1996) \\
\hline & 150 & 1992-2005 & & 34.2 & & Li et al. (2010) \\
\hline Northern slope of Mt. Bogda & 99 & $1962-2006$ & \multirow{2}{*}{12} & 16.9 & 3.6 & Li et al. (2011) \\
\hline Southern slope of Mt. Bogda & 104 & $1962-2006$ & & 25.3 & 4.5 & Li et al. (2011) \\
\hline & - & $1971 / 72-2001 / 02$ & - & 5.3 & - & Wang et al. (2009) \\
\hline Mt. Karlik Region & 75 & $1972-2005$ & 4 & 10.5 & 5.0 & $\begin{array}{l}\text { Li et al. (2011); Wang et } \\
\text { al. (2011) }\end{array}$ \\
\hline
\end{tabular}

Note: -, no data available.

Table 3 Information of 14 meteorological stations along the ridge line of the Chinese Tianshan Mountains

\begin{tabular}{|c|c|c|c|}
\hline Meteorological station & Location & Elevation (m) & Observation period \\
\hline Torugart & $40.52^{\circ} \mathrm{N}, 75.40^{\circ} \mathrm{E}$ & $3,504.4$ & 1960-2009 \\
\hline Akqi & $40.93^{\circ} \mathrm{N}, 8.45^{\circ} \mathrm{E}$ & $1,984.9$ & 1960-2009 \\
\hline Zhaosu & $43.15^{\circ} \mathrm{N}, 81.13^{\circ} \mathrm{E}$ & $1,851.0$ & 1960-2009 \\
\hline Baicheng & $41.78^{\circ} \mathrm{N}, 81.9^{\circ} \mathrm{E}$ & $1,229.2$ & 1960-2009 \\
\hline Wenquan & $44.97^{\circ} \mathrm{N}, 81.02^{\circ} \mathrm{E}$ & $1,354.6$ & 1960-2009 \\
\hline Bayanbulak & $43.03^{\circ} \mathrm{N}, 84.15^{\circ} \mathrm{E}$ & $2,458.0$ & 1960-2009 \\
\hline Baluntai & $42.67^{\circ} \mathrm{N}, 86.33^{\circ} \mathrm{E}$ & $1,752.5$ & 1960-2009 \\
\hline Urumqi & $43.78^{\circ} \mathrm{N}, 87.62^{\circ} \mathrm{E}$ & 917.9 & 1960-2009 \\
\hline Dabancheng & $43.35^{\circ} \mathrm{N}, 88.32^{\circ} \mathrm{E}$ & $1,103.5$ & 1960-2009 \\
\hline Kumux & $42.23^{\circ} \mathrm{N}, 88.22^{\circ} \mathrm{E}$ & 922.4 & 1960-2009 \\
\hline Qitai & $44.02^{\circ} \mathrm{N}, 89.57^{\circ} \mathrm{E}$ & 793.5 & 1960-2009 \\
\hline Shisanjianfang & $43.48^{\circ} \mathrm{N}, 91.63^{\circ} \mathrm{E}$ & 873.2 & 1960-2009 \\
\hline Barkol & $43.60^{\circ} \mathrm{N}, 93.00^{\circ} \mathrm{E}$ & $6,650.0$ & 1960-2009 \\
\hline Yiwu & $43.27^{\circ} \mathrm{N}, 94.70^{\circ} \mathrm{E}$ & $1,728.6$ & 1960-2009 \\
\hline
\end{tabular}

\section{Analyses and discussion}

\subsection{Regional differences of glacial changes and driving forces}

Researchers conducted a number of studies about mass balances on UG1 (Liu et al., 1998; Yang et al., 2005; Li et al., 2011; Dong et al., 2012; Zhang et al., 2014). During 1959-2010, the cumulative mass balance observed was $-14,883 \mathrm{~mm}$ water equivalent with a mean annual mass balance of $-286 \mathrm{~mm}$ water equivalent. The equilibrium line altitude (ELA) showed a significant ascending trend with a recently reported value of ca. $90 \mathrm{~m}$ (Zhang et al., 2014). Sporadic observations have been conducted on Qingbingtan Glacier No. 72 and Keqikar Glacier (Fig. 2). For Qingbingtan Glacier No. 72, the net ablation was -162 mm water equivalent during July to August 2008 as observed through two ablation sticks at the elevation of 3,950 m (Luo et al., 2012). The mass balances of Keqikar Glacier were -494 and $-383 \mathrm{~mm}$ for the year 2003/2004 and 2004/2005 with the ELA risen ca. 


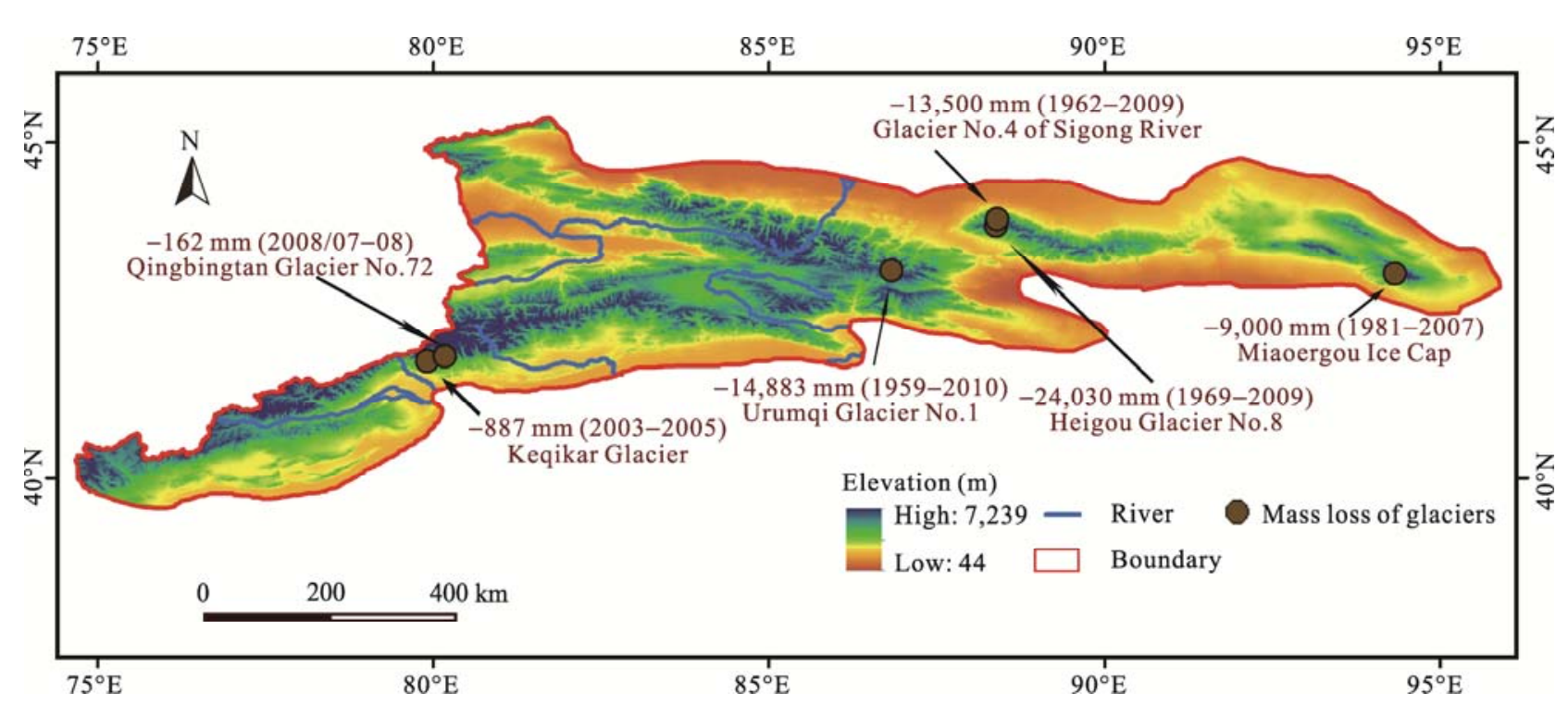

Fig. 2 Mass losses of glaciers in the Chinese Tianshan Mountains. The mass losses for Urumqi Glacier No. 1, Qingbingtan Glacier No. 72 and Keqikar Glacier are based on in-situ observations, while the values for Glacier No. 4 of Sigong River, Heigou Glacier No. 8, and Miaoergou Ice Cap are estimated by multiplying the ice thickness changes by the ice density. The ice density is assumed to be $0.9 \times 10^{3} \mathrm{~kg} / \mathrm{m}^{3}$.

$300 \mathrm{~m}$ compared with that in the 1970s (Zhang et al., 2006). Although mass balances were not measured for those two glaciers, changes in ice thickness (i.e., geodetic mass balance method) can be an effective method used to acquire glacier mass balances via multiplication with the ice density. We assumed the ice density as $0.9 \times 10^{3} \mathrm{~kg} / \mathrm{m}^{3}$ in this study to convert ice thickness into cumulative mass balance. The average thickness of Glacier No. 4 of the Sigong River Basin was $27.6 \mathrm{~m}$ with an ice volume of $76.0 \times 10^{6} \mathrm{~m}^{3}$ in 2009 (Wu et al., 2011). From 1962 to 2009, the glacier tongue thinned by $15 \pm 8 \mathrm{~m}$ with an ice volume loss of $0.014 \pm 0.008 \mathrm{~km}^{3}$ that corresponds to an average annual balance of $-0.29 \pm 0.15 \mathrm{~m}$ water equivalent (Wang et al., 2012). Glacier thickness varied significantly with elevation and the glacier thinning was strong at lower elevations. Wu et al. (2013) found that the thinning of Heigou Glacier No. 8 increased from $0.42 \pm 0.56 \mathrm{~m} / \mathrm{a}$ in $1969-2000$ to $1.47 \pm 0.79 \mathrm{~m} / \mathrm{a}$ in 2000-2008, and then accelerated to $1.92 \pm 0.98 \mathrm{~m} / \mathrm{a}$ in 2008-2009. For Miaoergou Ice Cap, the ice thickness decreased by $0-20 \mathrm{~m}$ varied with locations during 1981-2007. The melting mainly occurred in the lower part of the ice cap with slight melting at the top. Ice core data indicated that glacier melting accelerated in the last 20-30 years ( $\mathrm{Li}$ et al., 2007). The cumulative mass bal- ance was approximately $-24,030 \mathrm{~mm}$ water equivalent from 1969 to 2009 for Heigou Glacier No. 8 and about $-9,000 \mathrm{~mm}$ water equivalent from 1981 to 2007 for the Miaoergou Ice Cap.

Terminus change as a glacial parameter can be relatively easy to obtain. During the past five decades, terminus changes have been determined for the 12 monitored glaciers in the Chinese Tianshan Mountains (Fig. 3). Among them, terminus changes of UG1 have been observed annually since 1959 . Observations indicated that the terminus of UG1 retreated at a rate of $4.5 \mathrm{~m} / \mathrm{a}$ for the period from 1959-1993. The two branches of UG1 separated in 1993; serious ablation caused the east and the west branches to retreat at rates of 6.0 and $3.5 \mathrm{~m} / \mathrm{a}$, respectively (Li et al., 2011). For the other glaciers, terminus changes were determined by comparing various data from different periods (Chen et al., 1996; Kang, 1996; Li et al., 2006, 2010, 2011; Wang et al., 2009, 2011; Gao et al., 2011). Area changes of nine glacial basins were studied using topographic maps, aerial photographs, satellite images and digital elevation models (DEMs). Larger glacier shrinkage occurred in the central Chinese Tianshan Mountains. Between 1964 and 2005, the glacier areas of the Urumqi River Basin and the Toutun River Basin re- 
duced by $34.2 \%$ and $31.5 \%$, respectively. The area reductions were relatively smaller for glaciers in the east and the west parts of the Tianshan Mountains than in the central part (Fig. 4).

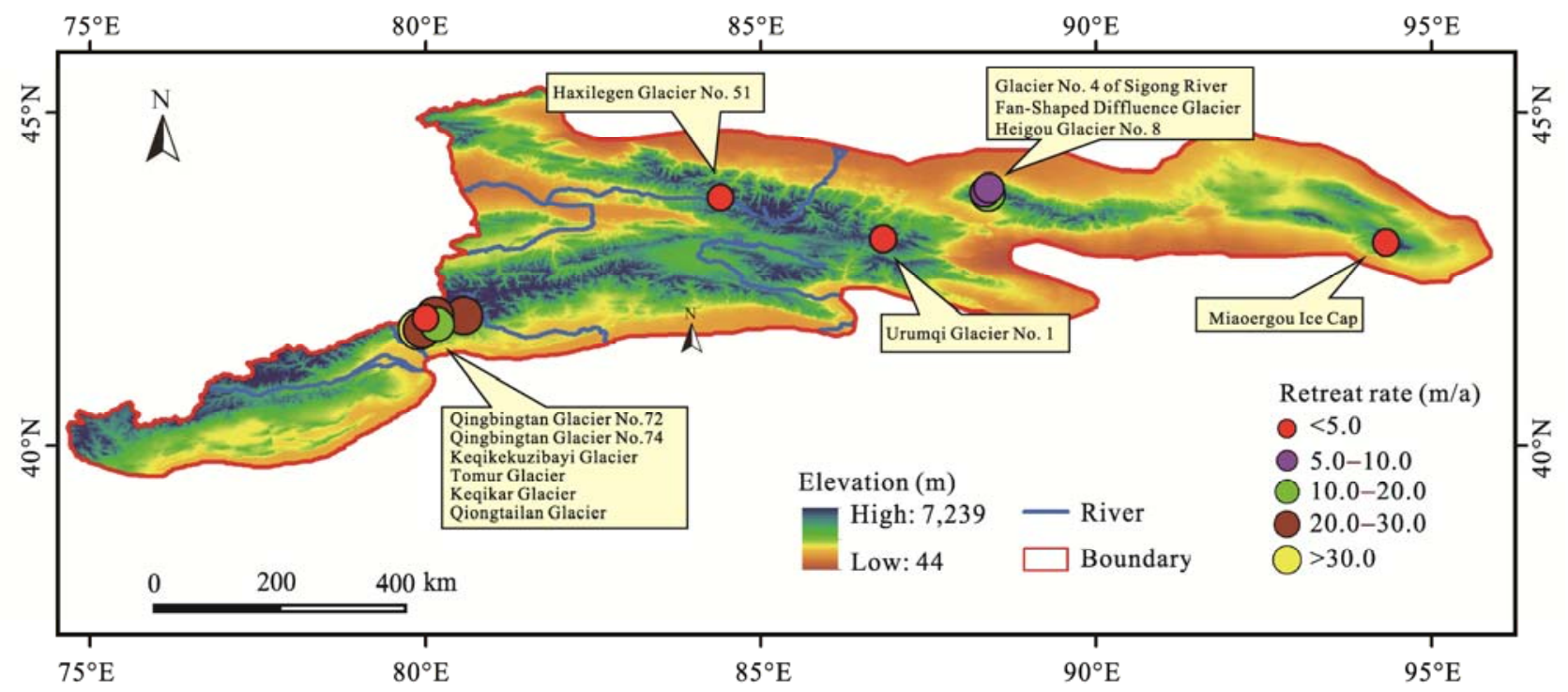

Fig. 3 Terminus retreats of 12 monitored glaciers in the Chinese Tianshan Mountains

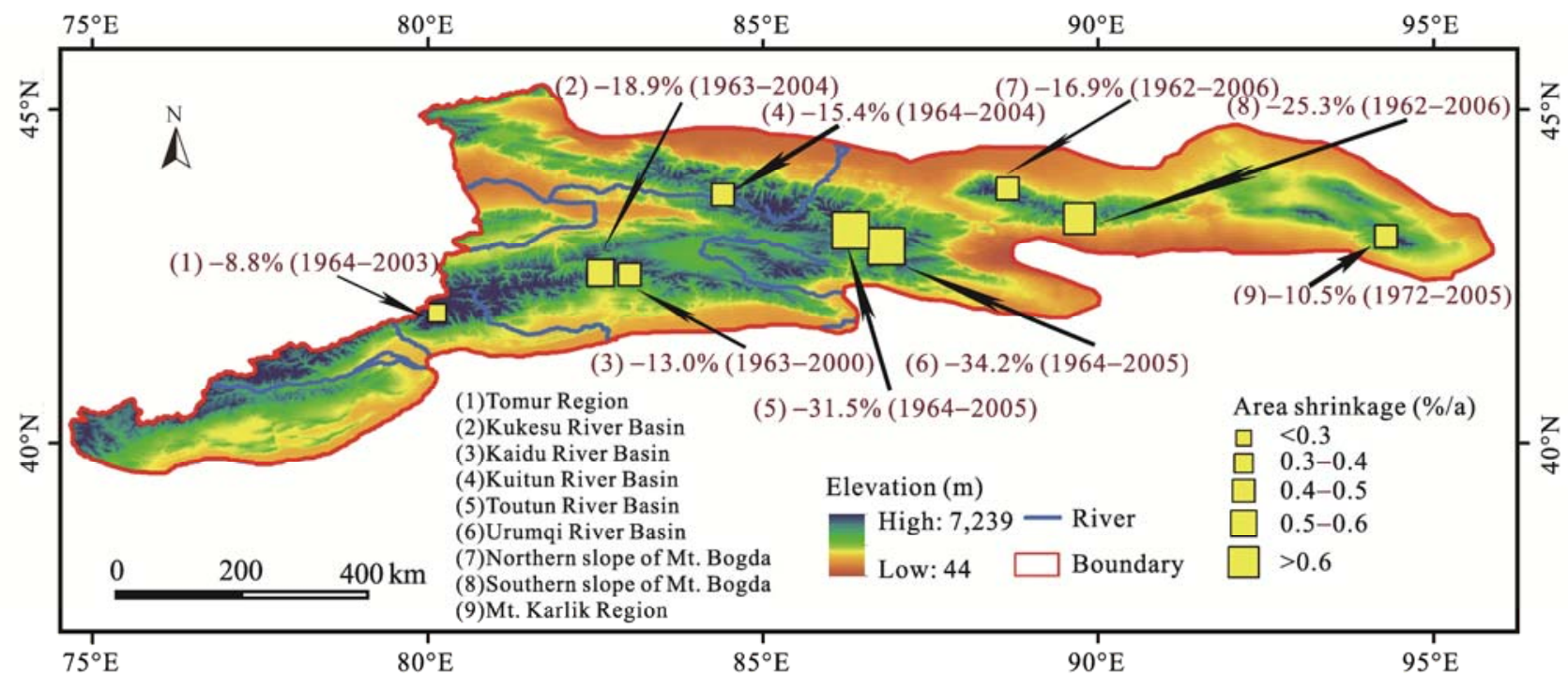

Fig. 4 Area shrinkage of glaciers in the 9 glacial basins in the Chinese Tianshan Mountains

Temperatures increased remarkably in the Chinese Tianshan Mountains, as confirmed by nearly 50 years of records from 14 meteorological stations (Fig. 1; Table 3). The temperature increased by an average rate of $0.34^{\circ} \mathrm{C} / 10 \mathrm{a}$ from 1960 to 2009 , being consistent with the temperature trend throughout Xinjiang $\left(0.33^{\circ} \mathrm{C} / 10 \mathrm{a}\right)$. Meanwhile, the average precipi- tation in the Chinese Tianshan Mountains increased by $11 \mathrm{~mm} / 10$ a (Fig. 5 ).

With climatic warming, trends of glacier mass loss, terminus retreat, and area shrinkage have been observed since the mid- $20^{\text {th }}$ century throughout the Chinese Tianshan Mountains. Regional differences of glacial changes were also influenced by glacier sizes, 


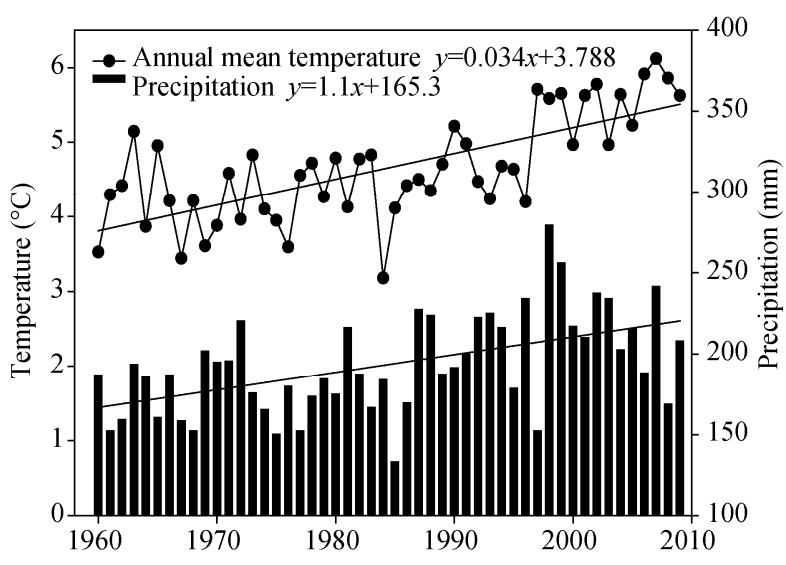

Fig. 5 Variation of annual mean temperature and precipitation in the Chinese Tianshan Mountains during 1960-2009

altitude and aspect. Glaciers in the Tomur Region had the highest altitude among the glaciers of 9 glacial basins (Shi et al., 2005). Glaciers in the Mt. Karlik Region were also at relatively high altitude. However, the highest altitude of the glaciers in the central Chinese Tianshan Mountains (e.g., the Urumqi River Basin and the Toutun River Basin), was similar to the lowest altitude of the glaciers in the Tomur Region. In general, glaciers at higher altitude responded slowly to climate change and vice versa. The behaviors of the six glaciers in the Tomur region differed on topographical factors as well (Wang et al., 2013; Fig. 4).

Glacier size is another important factor that influences glacier response to climate change (Bahr et al., 1998). The glaciers in the Urumqi River Basin and the Toutun River Basin were relatively small while $40 \%$ of the glaciers in the Tomur Region were larger than $1 \mathrm{~km}^{2}$. Small glaciers experienced a higher rate of surface loss. The great amount of solar radiation received on the southern slope caused intensive glacial retreat than in other aspects. The north and the south wings of Mt. Bogda are asymmetrical with the southern slope being less steep than the north (Lanzhou Institute of Glaciology and Geocryology and Chinese Academy of Sciences, 1986b). As a result, a large proportion of the Mt. Bogda glaciers occurred on the southern slope. This spatial distribution pattern was further confirmed by the differences in changes between Glacier No. 4 of Sigong River on the northern slope and Heigou Glacier No. 8 on the southern slope (Fig. 3).

\subsection{Potential effects on water resources}

Glaciers in the Chinese Tianshan Mountains act as a huge alpine reservoir and play an extremely important role in the regulation of river runoff in Xinjiang Uygur autonomous region (Xinjiang). Glacier meltwater runoff decreases during wet-cold periods because of deficient heat energy, weak melting and increased glacier accumulation while meltwater runoff increases during dry-hot periods due to increased insolation and intensified glacier ablation. Glaciers can regulate the annual distribution of river runoff. With little rainfall in summer, glacier meltwater is the main source of the river water supply. During storm and seasons with great amounts of precipitation, glaciers can conserve and retain part of precipitation to reduce flood hazards in downstream areas. The runoffs of the most rivers in Xinjiang are stable with small inter-annual variations. The coefficient between the annual runoff variation and the amount of glacier meltwater is $0.1-0.5$ and decreased as the proportion of glacier meltwater increased, with a minimum reported value of $0.1-0.2$ (Yang, 1991).

Climatic warming has caused rapid retreat of most glaciers in Xinjiang with $11.7 \%$ reduction in glacier areas during the past four decades ( $\mathrm{Li}$ et al., 2010). The present estimated meltwater runoff exceeded $200 \times 10^{8} \mathrm{~m}^{3}$, accounted for more than $25 \%$ of the total surface water runoff $\left(789 \times 10^{8} \mathrm{~m}^{3}\right.$; Li et al., 2003, 2009). Measured annual runoff at Glacier No. 1 gauging station was $194 \times 10^{4} \mathrm{~m}^{3} / \mathrm{a}$ during 1959-2008 (Fig. 6a; Sun et al., 2013). As shown in Fig. 6b, the annual runoff had significant seasonal variations and the runoff was concentrated in June to August. Roughly $62.8 \%-72.1 \%$ of increased river runoff was due to the mass losses of Urumqi Glacier No. 1 (Sun et al., 2013). Strong ablation of glaciers can produce large quantities of water in a short term, which could produce unexpected hazards. In serious ablation periods, higher amounts of glacier meltwater could lead to the out-bursting of glacier-dammed lakes, causing sudden flood damages. This scenario requires special attention and prevention measures should be formulated. Additionally, the regulation of river runoff can be weakened. However, ablation can also lead to substantial drops in the glacier solid mass and an eventual 
decrease in meltwater generation. Previous studies indicated that glacier lakes in the Tianshan Mountains expanded at a rate of $0.689 \mathrm{~km}^{2} / \mathrm{a}$ or $0.8 \% / \mathrm{a}$. The glacier lakes in the eastern Tianshan Mountains contributed to over half of the expansion with a rate of $0.352 \mathrm{~km}^{2} / \mathrm{a}$ (Wang et al., 2013). Furthermore, glacier lake expansion can evidently slow the regional glacier melt water losses because glacier lakes held approximately $6 \mathrm{Mt}$ of glacier meltwater each year in the Tianshan Mountains during 1990-2010. Additionally, the expansion may simultaneously increase the frequency and intensity of damages from floods or debris flows in this region. For Merzbacher Lake in the source region of the Kumarik River, glacier flash floods occurred 62 times in the period of 1932-2008. The total discharge of glacier flash floods increased from $1 \times 10^{8} \mathrm{~m}^{3}$ in the $1960 \mathrm{~s}-1970$ s to $3 \times 10^{8}-4 \times 10^{8} \mathrm{~m}^{3}$ in the 1990s and the total flood volume was as high as $4.5 \times 10^{8} \mathrm{~m}^{3}$. Therefore, glacier meltwater and flash floods play important roles in runoff supply and create flood control issues for the Tarim River in China (Shen et al., 2009).

The effect of the glacier recession on water resources varies spatially because of the differences in glacier distributions, characteristics of ongoing changes and proportion of the glacier meltwater in the river runoff. Glaciers in the Tomur region are sources of the Tarim River, the longest inland river in China. Currently, these glaciers are slowly melting, and the amount of glacier meltwater runoff is expected to remain stable in the near future (Li et al., 2010). However, climate warming will increase the sensitivity of the meltwater runoff to climatic changes which will exacerbate the low water level in cold years. Once the majority of glaciers have melted, glacier runoff would drop sharply and be ended up at a very low level. Further observations are urgently needed because systematic observation data are not available. There are uncertainties in glacier time-scale change predictions as the existing data time series were too short. Overall, glacier water play a pivotal role in the Tarim Basin. Glaciers are in a state of ablation at present and the potential reductions in water supply are expected to have disastrous effects on the economy and environ- ment of this region.

The water supply system in Xinjiang is vulnerable and highly dependent on glacier meltwater. Based on observation data from three hydrological stations in Hami, Xinjiang (Wang et al., 2011), the runoffs of rivers without glacier meltwater supply, such as the Toudaogou River, decreased with the temperature increase although there was a slight increase in precipitation in recent years. The runoff process reflected the effects of glacier changes on hydrology through the availability and variations of melting water, which is mainly characterized by a general decrease in the availability of water resources (Wang et al., 2011). Glacier melting in the Mt. Karlik Region has accelerated and would finally constrict the river water supply.

The amount of small glaciers are numerous in the Chinese Tianshan Mountains. These glaciers are sensitive to climatic changes and are facing constant threats of extinction which would cause obvious landscape-scale changes. However, large glaciers dominate effects on river runoff. Few studies analyzed the response of large glaciers to climate change, the future changes in the availability of water supply as well as the processes. Time scale of glacial changes has not been fully understood. The future studies should conduct targeted observations and researches. This study is still limited to qualitative analysis which resulted in an uncertain estimation in the changes of the future glacier water resources in Xinjiang. An observation system of glaciers in different types and sizes should be established to enhance further studies to carry out more detailed glacier simulation predictions.

\section{Summary}

In the past five decades, the temperature in the Chinese Tianshan Mountains increased at an average rate of $0.34^{\circ} \mathrm{C} / 10 \mathrm{a}$. Glaciers in the Chinese Tianshan Mountains experienced dramatic terminus retreats, reduction in areas and mass losses. Remarkable regional differences were observed in recent decades due to variations in climatic conditions and the sizes of glaciers. The glacier area reductions in the central Chinese Tianshan Mountains (Urumqi River Basin, 

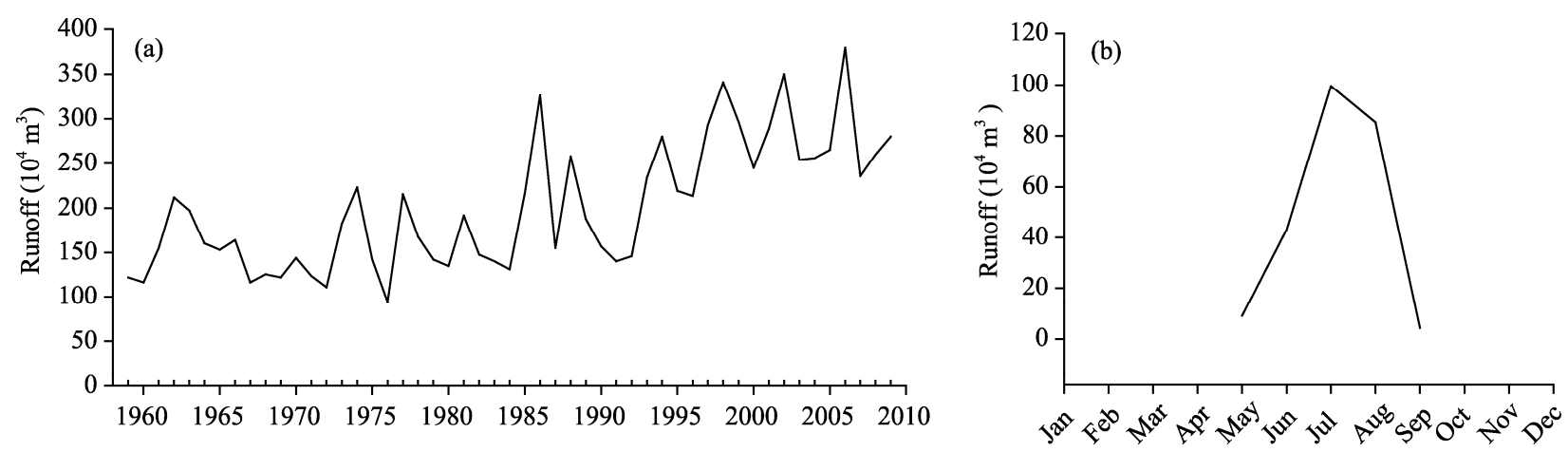

Fig. 6 (a) Annual change and (b) monthly distribution of the runoff at the Glacier No. 1 Gauging Station during 1959-2008

34.2\%; Toutun River Basin, 31.5\%) was larger than that in the eastern and the western parts; the monitored glaciers in these areas experienced unique changes. The effects of glacier recession on water supplies to the rivers in the Chinese Tianshan Mountains exhibited spatial variations which were caused by glacier distributions, characteristics of glacier terminus, area, thickness and volume changes, as well as the proportion of glacier meltwater in river runoff. However, it is difficult to discuss the quantitative effects of glacier changes on water supplies in the various regions because of the limited observational data in glacier types and sizes. The complexity of climate change coupled with the dynamic responses of individual glaciers exacerbated this problem.

Future studies should focus on 1) continuous observation on long-term monitored glaciers, 2) establishing an area-volume empirical formula that is directly related to the availability of water resources under the present climatic condition, and 3) in-depth analysis of the dynamic response of glaciers to climate change. Integrated field observations and appropriate modeling would be helpful to enrich our scientific knowledges about the mountain glaciers and their effects on water supplies.

\section{Acknowledgements}

This work was funded by the Funds for Creative Research Groups of China (41121001), the National Basic Research Program (2013CBA01801), the National Natural Science Foundation of China (41301069, 41471058), the State Key Laboratory of Cryospheric Science foundation, Cold and Arid Regions Environmental and Engineering Research Institute, Chinese Academy of Sciences (SKLCS-ZZ-2012-01-01), West
Light Program for Talent Cultivation of the Chinese Academy of Sciences, and the Special Financial Grant from the China Postdoctoral Science Foundation ( 2014T70948).

\section{References}

Aizen V B, Kuzmichenok V A, Surazakov A B, et al. 2007. Glacier changes in the Tien Shan as determined from topographic and remotely sensed data. Global and Planetary Change, 56(3-4): 328-340.

Bahr D B, Pfeffer W T, Sassolas C, et al. 1998. Response time of glaciers as a function of size and mass balance: 1. Theory. Journal of Geophysical Research, 103(B5): 9777-9782.

Bolch T. 2007. Climate change and glacier retreat in northern Tien Shan (Kazakhstan/Kyrgyzstan) using remote sensing data. Global and Planetary Change, 56(1-2): 1-12.

Cao Z T. 1993. Glacio-hydrological characteristics of Gozha glacier on south slope of the West Kunlun Mountains. Journal of Glaciology and Geocryology, 15(4): 582-589. (in Chinese)

Chen J M, Liu C H, Jin M X. 1996. Application of the repeated aerial photogrammetry to monitoring glacier variation in the drainage area of the Urumqi River. Journal of Glaciology and Geocryology, 18(4): 331-336. (in Chinese)

Dong Z W, Qin D H, Ren J W, et al. 2012. Variations in the equilibrium line altitude of Urumqi Glacier No.1, Tianshan Mountains, over the past 50 years. Chinese Science Bulletin, 57(36): 4776-4783.

Gao W Y, Li Z Q, Li K M, et al. 2011. Glacier variation in the Kukesu River Basin during 1963-2004 based on remote sensing data and GIS techniques. Arid Land Geography, 34(2): 252-261. (in Chinese)

Jiao K Q, Jing Z F, Cheng P, et al. 2009. Monitoring results on the Glacier No.51 at Haxilegen in the Kuytun River Basin, Tianshan Mountains. Arid Land Geography, 32(5): 733-738. (in Chinese)

Jing Z F, Ye B S, Jiao K Q, et al. 2002. Surface velocity on the Glacier No.51 at Haxilegen of the Kuytun River, Tianshan Mountains. Journal of Glaciology and Geocryology, 24(5): 563-566. (in Chinese)

Kang E S. 1996. A study on changes of the glacier system and its runoff at the north flank of the Tianger Mountain in the Tianshan Mountains. Journal of Glaciology and Geocryology, 18(Suppl.): 60-74. (in Chinese) 
Kutuzov S, Shahgedanova M. 2009. Glacier retreat and climatic variability in the eastern Terskey-Alatoo, inner Tien Shan between the middle of the $19^{\text {th }}$ century and beginning of the $21^{\text {st }}$ century. Global and Planetary Change, 69(1-2): 59-70.

Lanzhou Institute of Glaciology and Geocryology, Chinese Academy of Sciences. 1986a. Glacier Inventory of China (III): Tianshan Mountains (Ili River Drainage Basin). Beijing: Science Press. (in Chinese)

Lanzhou Institute of Glaciology and Geocryology, Chinese Academy of Sciences. 1986b. Glacier Inventory of China (III): Tianshan Mountains (Interior Drainage Area of Scattered Flow in East). Beijing: Science Press. (in Chinese)

Lanzhou Institute of Glaciology and Geocryology, Chinese Academy of Sciences. 1986c. Glacier Inventory of China (III): Tianshan Mountains (Interior Drainage Area of Tarim Basin in Southwest). Beijing: Science Press. (in Chinese)

Lanzhou Institute of Glaciology and Geocryology, Chinese Academy of Sciences. 1986d. Glacier Inventory of China (III): Tianshan Mountains (Interior Drainage Area of Junggar Basin in Northwest). Beijing: Science Press. (in Chinese)

Li B L, Zhu A X, Zhang Y C, et al. 2006. Glacier change over the past four decades in the middle Chinese Tien Shan. Journal of Glaciology, 52(178): 425-432.

Li K M, Li Z Q, Gao W Y, et al. 2011. Recent glacial retreat and its effect on water resources in eastern Xinjiang. Chinese Science Bulletin, 56(33): 3396-3604.

Li Z Q, Han T D, Jing Z F, et al. 2003. A summary of 40-year observed variation facts of climate and Glacier No.1 at headwater of Urumqi River, Tianshan, China. Journal of Glaciology and Geocryology, 25(2):117-123. (In Chinese)

Li Z Q, Wang F T, Zhu G C, et al. 2007. Basic features of the Miaoergou Flat-topped Glacier in East Tianshan Mountains and its thickness change over the past 24 years. Journal of Glaciology and Geocryology, 29(1): 61-65. (in Chinese)

Li Z Q, Wang W B, Zhang M J, et al. 2009. Observed changes in streamflow at the headwaters of the Urumqi River, Eastern Tianshan, Central Asia. Hydrological Processes, 24(2): 217-224. doi: 10.1002/hyp.7431

Li Z Q, Li K M, Wang L. 2010. Study on recent glacier changes and their impact on water resources in Xinjiang, North Western China. Quaternary Sciences, 30(1): 96-106. (in Chinese)

Li Z Q, Li H L, Chen Y N. 2011. Mechanisms and simulation of accelerated shrinkage of continental glaciers: a case study of Urumqi Glacier No.1 in eastern Tianshan, central Asia. Journal of Earth Science, 22(4): 423-430.

Li Z X, He Y Q, Xin H J, et al. 2010. Spatio-temporal variations of temperature and precipitation in Mts. Hengduan Region during 1960-2008. Acta Geographica Sinica, 65(5): 563-579. (in Chinese)

Liu S Y, Ding Y J, Wang N L, et al. 1998. Mass balance sensitivity to climate change of the Glacier No.1 at the Urumqi River Head, Tianshan Mts. Journal of Glaciology and Geocryology, 20(1): 9-13. (in Chinese)

Liu S Y, Ding Y J, Shangguan D H, et al. 2006. Glacier retreat as a result of climate warming and increased precipitation in the Tarim river basin, Northwest China. Annals of Glaciology, 43(1): 91-96.
Liu S Y, Yao X J, Guo W Q, et al. 2015. The contemporary glaciers in China based on the Second Chinese Glacier Inventory. Acta Geographica Sinica, 70(1): 3-16. (in Chinese)

Luo Y, Li H L, Li Z Q, et al. 2012. The relationship between the mass balances and meteorological factors at the glacier of No.72, Qingbingtan, Shenqi Peak, Tuomuer Area. Journal of Arid Land Resources and Environment, 26(3): 62-67. (in Chinese)

Mountaineering and Expedition Term of Chinese Academy of Sciences. 1995. Glacial and Weather in Mt. Tuomuer District, Tianshan. Urumqi: Xinjiang People's Publishing House, 32-98. (in Chinese)

Narama C, Kääb A, Duishonakunov M, et al. 2010. Spatial variability of recent glacier area changes in the Tian Shan Mountains, Central Asia, using Corona $(\sim 1970)$, Landsat $(\sim 2000)$, and ALOS $(\sim 2007)$ satellite data. Global and Planetary Change, 71(1-2): 42-54.

Shen Y P, Wang G Y, Ding Y J, et al. 2009. Changes in Merzbacher Lake of Inylchek Glacier and glacial flash floods in Aksu River Basin, Tianshan during the period of 1903-2009. Journal of Glaciology and Geocryology, 31(6): 993-1002. (in Chinese)

Shi Y F, Liu C H, Wang Z T, et al. 2005. A Concise China Glacier Inventory. Shanghai: Shanghai Science Popularization Press. (in Chinese)

Su Z, Sun G P, Wang L L, et al. 1985. Modern glacier in Mt. Tuomuer district. In: Su Z, Kang E S. Glacial and Weather in Mt. Tuomuer District, Tianshan. Urumqi: Xinjiang People's Publishing House, 32-88. (in Chinese)

Su Z. 1998. Glaciers and Environment of the Karakorum-Kunlun Mountains. Beijing: Science Press. (in Chinese)

Sun M P, Li Z Q, Yao X J, et al. 2013. Rapid shrinkage and hydrological response of a typical continental glacier in the arid region of northwest China-taking Urumqi Glacier No.1 as an example. Ecohydrology, 6(6): 909-916.

Wang L, Li Z Q, Wang F T, et al. 2014. Glacier shrinkage in the Ebinur lake basin, Tien Shan, China, during the past 40 years. Journal of Glaciology, 60(220): 245-254.

Wang L L, Liu C H, Kang X C, et al. 1983. Fundamental features of modern glaciers in the Altay Shan of China. Journal of Glaciology and Geocryology, 5(4): 27-38. (in Chinese)

Wang S H, Xie Z C, Li Q Y. 2008. Comparison study of glacier variations in East and West Tianshan Mountains. Journal of Glaciology and Geocryology, 30(6): 946-953. (in Chinese)

Wang P Y, Li Z Q, Li H L, et al. 2011. Ice surface-elevation change and velocity of Qingbingtan glacier No.72 in the Tomor region, Tianshan Mountains, central Asia. Journal of Mountain Science, 8(6): 855-864.

Wang P Y, Li Z Q, Li H L, et al. 2012. Glacier No.4 of Sigong River over Mt. Bogda of eastern Tianshan, central Asia: thinning and retreat during the period 1962-2009. Environmental Earth Sciences, 66(1): 265-273.

Wang P Y, Li Z Q, Wang W B, et al. 2013. Changes of six selected glaciers in the Tomor region, Tian Shan, Central Asia, over the past $\sim 50$ years, using high-resolution remote sensing images and field surveying. Quaternary International, 311: 123-131.

Wang P Y, Li Z Q, Li H L, et al. 2014. Comparison of glaciological and geodetic mass balance at Urumqi Glacier No.1, Tian Shan, Central 
Asia. Global and Planetary Change, 114: 14-22.

Wang S J, Zhang M J, Li Z Q, et al. 2011. Glacier area variation and climate change in the Chinese Tianshan Mountains since 1960. Journal of Geographical Sciences, 21(2): 263-273.

Wang W B, Li K M, Gao J F. 2011. Monitoring glacial shrinkage using remote sensing and site-observation method on southern slope of Kalik Mountain, eastern Tian Shan, China. Journal of Earth Science, 22(4): 503-514.

Wang X, Wu K P, Jiang L H, et al. 2013. Wide expansion of glacial lakes in Tianshan Mountains during 1990-2010. Acta Geographica Sinica, 68(7): 983-993. (in Chinese)

Wang Y T, Hou S G, Liu Y P. 2009. Glacier changes in the Karlik Shan, eastern Tien Shan, during 1971/72-2001/02. Annals of Glaciology, 50(53): 39-45.

Wang Z T. 1987. Influence of supraglacial moraine on surface ablation and ice temperature of glaciers. In: The Lanzhou Institute of Glaciology and Geocryology, CAS. Proceedings of the $2^{\text {nd }}$ National Conference on Glaciology of the Geographical Society of China. Lanzhou: The People's Publishing House of Gansu, 131-139. (in Chinese)

Wang Z T. 1991. A discusion on the questions of development of Heigou Glacier No.8, Bogda-peak Region. Journal of Glaciology and Geocryology, 13(2): 141-146, 158. (in Chinese)

Wu G H, Zhang S Y, Wang Z X. 1983. Retreat and advance of modern glaciers in Bogda, Tianshan. Journal of Glaciology and Geocryology, 5(3): 143-152. (in Chinese)

Wu L H, Li Z Q, Wang P Y, et al. 2011. Sounding the Sigong River Glacier No.4 in Mt. Bogda area, the Tianshan Mountains by using ground penetrating radar and estimating the ice volume. Journal of Glaciology and Geocryology, 33(3): 276-282. (in Chinese)

Wu Z, Liu S Y, Zhang S Q, et al. 2013. Accelerated thinning of Hei Valley No.8 Glacier in the Tianshan Mountains, China. Journal of Earth Science, 24(6): 1044-1055.

Xie C W, Ding Y J, Liu S Y, et al. 2006. Variation of Keqikaer Glacier terminus in Tomur Peak during last 30 years. Journal of Glaciology and Geocryology, 28(5): 672-677. (in Chinese)

Yang H A, Li Z Q, Ye B S, et al. 2005. Study on mass balance and process of Glacier No.1 at the headwaters of the Urumqi River in the past 44 years. Arid Land Geography, 28(1): 76-80. (in Chinese)

Yang Z N. 1991. Glacier Water Resources in China. Lanzhou: Gansu Science and Technology Press, 81-150. (in Chinese)

Zhang G F, Li Z Q, Wang W B, et al. 2014. Rapid decrease of observed mass balance in the Urumqi Glacier No.1, Tianshan Mountains, central Asia. Quaternary International, 349: 135-141.

Zhang Y, Liu S Y, Ding Y J, et al. 2006. Preliminary study of mass balance on the Keqicar Baxi Glacier on the south slopes of Tianshan Mountains. Journal of Glaciology and Geocryology, 28(4): 477-484. (in Chinese) 